\title{
Developing States Challenge ICSID
}

\author{
Jia Liu \\ Law School, Xiamen University, Xiamen 361000, China \\ jiabao12055@163.com
}

\begin{abstract}
ICSID (International Centre for Settlement of Investment Disputes) plays important role in resolving international investment disputes and enhancing international investment. But this mechanism also faces a lot of criticize from developing countries. Because the core international investment theory of developing counties is different from developed countries, they hold different opinions toward the performance of ICSID. And in practice, ICSID does ignore the interest of developing countries under some situations. This paper is going to introduce developing countries negative attitude toward ICSID through empirical research and try to find out methods to perfect international investment dispute mechanism from the aspect of developing countries.

Index Terms - ICSID, Developing Countries, Investment Treaty
\end{abstract}

\section{Introduction}

After 1990s, more and more bilateral investment treaties and regional trade agreement provided provisions to resolve international investment disputes. Foreign investors are authorized to trigger international arbitration under the condition that host country acts against its treaty obligations. As the rapid flow of international capital, more and more investment disputes appear. Most foreign investors come from developed countries but most host countries are developing countries. Under some conditions, in order to realize public interest to protect its natural resource or environment, developing countries take measures against foreign investment. The core of developed countries' international investment jurisprudence is rule-oriented investment judicial system, the value orientation bases on free market theory. So developed country pay a lot attention to international economic rules, competition mechanism, interest of multinational company, and investment freedom. But the value orientation of developing countries' international investment law is to save as much space as possible for government intervention under the reorganization of market economy. Developing countries strengthen national economic sovereignty and keep alarm with international economic rules and dispute settlement system. But the traditional international investment arbitration system emphasized the protection of investors' ownership. This makes developing countries face negative situation always. Their behaviors performing economic sovereignty are always judged to be illegal and their state sovereignty as well as national interest can not be protected reasonably. The paper discusses developing countries attitude toward current ICSID to show challenges to it from developing countries. And explores problems faced by ICSID and the possible measures can be taken to perfect it.

\section{General Challenges of ICSID from Developing Countries}

Because general international commercial arbitration roots in the concept of the division of public power and private right that is called non-political area. Liberalistic philosophy dominant the whole process of commercial investment disputes settlement. Liberalistic philosophy views all disputes as property ownership disputes which is totally different from disputes relating state sovereignty. It pays no attention to state sovereignty and host countries' economic sovereignty, public interest but only protect property ownership. Therefore, the current system creates series confusion about the eroding of state sovereignty and public interest from unlimited exaggerations of private rights. This phenomenon is even criticized by some organizations as the bankrupting democracy of ICSID. Due to the above mentions democracy crisis, a lot of developing countries take a series of measures to escape from jurisdiction of ICSID to protect their state sovereignty and public interest.

\section{A. General Situations in Latin American Countries}

During past twenty years, the cases submitted to ICSID have been rapidly growing. And the cases heard by ICSID covering a lot of Latin American Countries measures relating to public interest. For example but do not limit to public welfare, healthy, environmental protection, national security and economy. From 1996 to 2011, ICSID accepted 355 cases, 137 of which relating to Latin American Countries counting for $39 \%$ of total amount. 49 of 137 cases against Argentina including 26 undecided cased accounting for 39\% of total undecided cases relating Latin American Countries in ICSID and 23 decided cases. In the 23 decided cases relating to Argentina, 8 cases gained final verdict, 15 cased withdraw or the investors reached agreement with Argentina government. In 8 cases, 1 case did not make public, 3 cases support the claims of Argentina government and 4 cases of Argentina government's claims was overruled. Accordingly, in 25 undecided cases, 6 of them suspended due to the reaching of bilateral agreements and the reminding cases are still in process. For 12 member states of UNASUR (Union of South American Nations), 9 member states face 108 arbitrations in ICSID most of them concerning natural resources.

During the process of participating arbitration, Latin American Countries realized except their own problems, there are also problems existing in ICSID injuring Latin American Countries national benefits. ICSID lacks transparency, ignoring public interest, verdict consistency, appellate procedure and so on. Hence, some Latin American Countries 
raised objections against ICSID or even claimed to withdraw ICSID and reach new BIT (Bilateral Investment Treaty) to exclude ICSID jurisdiction. On the one hand Latin American Countries claim to exclude ICSID jurisdiction, on the other hand they emphases the importance of constructing regional arbitration center and take necessity practical practice. During recent years, China's investment in Latin American Countries growing quickly and it is meaningful for China to explore Latin American Countries attitude to ICSID.

In 2007, Bolivia, Venezuela and Nicaragua claims to withdraw ICSID to protect their state sovereignty and settle the foreign investment in their territory by themselves. Bolivia expressed the main reasons to withdraw ICSID: (1) it is lack of appellate procedure but the verdict is final verdict; (2) it is lack of independency, investors won 230 cases in 232 arbitrations; (3) the jurisdiction of ICSID against Bolivia Constitution Article 135 and the Constitution Court already announced the illegality of ICSID; (4) it only hear the arbitration submitted by foreign investors; (5) the procedure of arbitration is arbitrary; (6) the arbitration procedure is not public; (7) the cost of hiring solicitors is expensive and according to statistic the average cost of solicitor cost is $4,000,000$ USD every year. And Bolivia decided to start new negotiation and modify its mutual investment treaty. [1]

After that, the President of Venezuela also claimed to withdraw. In 2008, Venezuela took a series of measures against ICSID arbitration to exclude the ICSID jurisdiction on nationalization. Because Holland supports the jurisdiction of ICSID, Venezuela abolished its bilateral investment treaty in 2008. And the Supreme Court of Venezuela issued 1541 verdict pointing out foreigners could not make use of its domestic law or treaties to sue in ICSID unilaterally. And the Minister of Justice of Nicaragua reaffirmed they were considering to abolish ICSID and they would not sign any investment treaties involving ICSID jurisdiction.

In 2008, Ecuador issued new constitution. Article 422 of new constitution prohibited Ecuador to give up national arbitration jurisdiction referring contract or commence in any international treaties. However, Article 422 of new constitution only prohibited Ecuador to sign new agreement not including the signed international treaties and other international treaties differ from contract or commercial disputes. In order to enhance the establishment of Latin American Arbitration Center, Article 422 of new constitution stated, if Ecuador submitted disputes to Latin American Arbitration Center, it would not prohibit the sign of this kind of treaties.

In 2009, ICSID received announcement that Ecuador withdrawers ICSID and it would take effect after 6 months of acceptance. October 2009, President Rafael Correa proposed congress to withdraw all bilateral investment treaties since 1990 including treaties signed with American, British, German, France, Holland, Canada and China. Moreover, according to Article 422 of new constitution Ecuador restarted individual judicial review to judge if the BITs including its bilateral investment treaty with China harmed its national benefits and till now the above mentioned judicial review was still in process.

In 2009, Bolivia also passed Constitution promoting famous "Calvo Doctrine" in foreign investment field and specially providing in the field of gasoline and natural gas that it obtained absolute jurisprudence and prohibited to submit disputes relating to special industry to ICSID. However, some scholars believed from the aspect of international law, all these provisions are non-retroactive and they did not apply to any disputes happened before the change of Constitution. One state could not announce international treaties to be invalid through its domestic law or even Constitution.

The changing attitude toward ICSID and termination of some mutual investment treaties in Ecuador, Venezuela and Nicaragua initiated new and more complex legal problems with the arbitration system. All these countries do not view the existing ICSID legal system as perfect way to resolve disputes between them and investors. And all these nations get same characters: they all have important natural energy resources and prohibit the application of international arbitration procedure in the domestic Constitutions. Hence on the $7^{\text {th }}$ submit meeting of ALBA-TCP, member states suggested to establish a regional arbitration center to alternate ICSID and appointed a dispute settlement team to study and submit specific construction draft but till now the construction of regional arbitration center has not done.

Because Argentina is the country in Latin American Countries facing most of foreign investment disputes, this paper is gong to discuss its practice on ICSID in detail.

Firstly, the deficiency of parallel procedures or jurisprudence exists in ICSID. Basing on facts that shareholders in the same company sue to different arbitration tribunals but get different final verdicts, or different verdicts relating to similar legal problems or facts, the procedures of ICSID are in doubt. The above mentioned situation appeared in CMS v. Argentine Republic case and LG\&E Energy Corp v. Argentine Republic case. Although two arbitration tribunals achieved similar conclusion on core standards, for the issue of Argentine's emergency condition they both get contradictory conclusions.

Secondly, the appointment of arbitrator problem exists in ICSID. The provisions relating to the quality of arbitrators impair the fairness of ICSID. According to ICSID, investor can choose one arbitrator and host country can choose one, the Chief Arbitrator can be choosed by bilateral negotiation. Once they can not reach agreement, ICSID gets the right to appoint Chief Arbitrator. Considering the close relations between ICSID and World Bank, once World Bank holds investors' shares or gets important influence may bring unfair benefic conflicts. In Compañía de Aguas del Aconquija S.A. v. Argentine Republic case, International Bank for Reconstruction and Development played important role in public service franchise project and the establishment of privacy management procedure. Moreover the International Finance Corporation also held Compañía de Aguas del Aconquija S.A's share. Article 6(2) of ICSID Agreement 
requires arbitrators to sign announcement to indicate his record, profession, commercial activities, his relation with parties and any other situations may initiating one party's doubt with arbitrator's independency. However, ICSID arbitration provision does not provide any details relating to what kind of situation or relation suppose to be viewed as unfair. According to Article 14(1) the threshold of unqualified arbitrators is pretty high. But in UNCITRAL, the arbitration provision only requires applicant has reasonable doubt with the fairness and independency with arbitrators. In Compañía de Aguas del Aconquija S.A. v. Argentine Republic case, Argentina based on fact that in other forgoing cases Yves Fortier's law firm get relationship with Vivendi to doubt the arbitrator quality of Yves Fortier. But arbitration tribunal believed Yves Fortier's independency were not impaired by its custom relations with Vivendi and denied Argentina's objection.

Thirdly, the justifiability of ICSID is doubted by developing countries. A lot of arbitrations were raised after Argentina government took a series of political measures to handle the broken monetary system. Argentina government argued, according to provisions protecting investors from direct or in-direct nationalization, in order to prove its measure were illegal the following elements must be satisfied: (1) the foreigner investors suffered from non national treatment; (2) the government did not provide reasonable compensation and hider foreigner investors from suing in local courts. According to official opinion from Argentina, all above mentioned conditions are followed by it strictly. All the measures in disputes are generally applied and there were no discrimination toward foreign investors. All the measures did not violate investors' ownership and investors' opportunities to sue in local courts were not deprived.

Fourthly, necessity and emergent situation exist in developing countries. Argentina believed that gave up its primary monetary system and take special measures were the reflection of emergent situation. At that time, Argentina was suffered from most terrible economic crisis in its history. If it kept public business rate determined by UDS and the rate of price inflation unchanged, the poverty rate would be exaggerated. Moreover, public business got special authority in field of contract implementation and management of tariff rates. Although, domestic law and relative contracts has set system to adjust rates, government still believed it was necessary to cooperate with reasonable tariff level and practical custom incomes. And they believed companies being engaged in public business supposed to be viewed as normal business actors and their consequences should not be beard by public department. According to above mentioned opinion, even companies taking part in public business decided to bear risks due to the application of public economic measures, this kind of risks supposed to be viewed as normal business risk. And Argentina government pointed out during 1930s and Second World War, even American and British did not compensate companies suffered losses due to the giving up of primary gold standards and the suspending of its currency exchange policies. "Emergent situation" became the core of disputes in many investment disputes against Argentina. For example in CMS v. Argentine Republic case [2] and LG\&E Energy Corp., LG\&E v. Argentine Republic case [3]. In CMS v. Argentine Republic case the arbitration tribunal rejected Argentina's emergent situation argument, but after few years later in LG\&E v. Argentine Republic case the arbitration tribunal issued contradictory verdict accepting Argentina's emergent situation argument. But both arguments based on similar facts. And in other cases similar situations appeared also. In Sempra Energy Int'1 v. Argentina Republic case, arbitration tribunal rejected emergent situation argument and judged Argentina to compensate, but in 2010 the verdict overruled the primary judgment. [4]

Fifthly, ICSID is lack of appellate procedure. According to the basic principle of Argentina Constitution, referring to foreign investment disputes the BITs could not restrict domestic jurisdiction or against constitution and judicial review should be applied. However according to ICSID, the verdicts issued by ICSID arbitration tribunal could not be reviewed by domestic courts.

\section{B. Jurisprudence Roots of Argentina's Attitude}

Argentina Constitution is the highest law in its law hierarchy, all international treaties below it. Therefore, ICSID and BITs must follow the principles of Argentina Constitution.

All BITs belong to the treaties mentioned by Article 75(22)I of Argentina Constitution. And according to Article 31 of Argentina Constitution, these treaties' efficiency below Constitution but higher than domestic law. So Horacio Rosatti believed all ICSID verdicts supposed to be supervised by domestic courts.

Article 116 of Constitution authorize federal court jurisdiction to hear disputes relating to international treaties. Argentina recognizes jurisdiction of foreign countries but at the same time authorize one or more local courts authority to review and implement these verdicts. According to Argentina Constitution, ICSID supposed to be viewed as treaties signed with international organization and must accordance with public law principle stated by Argentina Constitution. The integration of BITs and ICSID procedure prohibits the proceeding of domestic review procedure and makes Argentina domestic law loses authority to initiate judicial review against relative verdicts. [5]

But some scholars believe that Argentina voluntarily sign mutual investment treaties and becomes the member state of ICSID. It means Argentina recognized abroad jurisprudence and domestic courts do not have right to apply judicial review. [6] Article 27 of ICSID requires member states to follow signed treaties and forbids them to reject the application of treaties under the name of domestic law. From the aspect of international law, even the efficiency of domestic constitution is higher than international treaty, it does not release one state's responsibility due to the denying of domestic constitution.

Even one country can claim ICSID, BITs and 
international verdict against constitution, it gets different effects in its own country territory and abroad. If one country claims one bilateral investment treaty against constitution, this country must withdraw the treaty. But it does not release that country's international responsibility. The judicial review issued by domestic courts is only valid domestically. However, if that state does not bear its international responsibility, it would suffer legal and economic sanctions from investors' motherland.

\section{Measures to Perfect ICSID}

Developing states suggest establish an alternative dispute settlement system including three aspects: the establishment of arbitration center; the establishment of investment dispute committee; the modification of behavior rules of UNASUR arbitrators. The arbitration center does not only accept investment disputes but also any other disputes needed help from center. The center accepts and hears investment disputes among member states and investment disputes between member states and other foreign investors. The center establishes pre-negotiation procedure and conciliation procedures. The center establishes jurisprudence or judicial case law and points out that it does not exclude the public policy principle proposed by sovereignty state. The committee will provide legal counsel, technical support especially in the field of dispute settlement study. At the beginning, arbitration center and consult committee only accept and hear disputes happed among member states. Later it can hear and accept disputes rising from Central America and Caribbean Sea states. At last it will open to all the states willing to apply it. [7] This kind of implementation is positive for stable development of arbitration center and consul committee. Except that, transparency and the establishment of appellate arbitration court are also important for the perfection of current ICSID.

\section{A. Transparency}

The arbitration is closed to public even parties get no exact ideas about what is going on in arbitration. Moreover there is no need for verdict of arbitration to make public totally. However, the shortcomings of CISID never prevent it from abolishing host countries' domestic law, doubting its legal system and challenging its environmental management policies. General commercial arbitration only referring to private interest, therefore the confidentiality of arbitration process is understandable and acceptable. But investment arbitration basing on international treaties always mention host countries' management measures to protect public health, financial security, environment and so on. All these measures affect public interest and it will be arguable for ICSID to apply confidentiality principle as normal commercial arbitration. No doubt the existence of confidentiality principle in ICSID will erode host countries' public interest and state sovereignty. Hence, it is necessary to take measures to make necessary process public to balance host countries' state sovereignty and investors' private interest.

\section{B. Appellate Procedure}

Under ICSID the only remedy method of verdict is to apply ICSID to withdraw it, any parties in dispute can not seek any other remedies including but do not limit to domestic judicial remedy. The remedy only limit to procedure reasons and ICSID does not oblige to withdraw verdict when they are facing procedure problems. Some scholars show their worrying about the independency and fairness of arbitration verdict. Therefore it is necessary to establish appellate procedure to provide remedy for parties. The appellate arbitration can sustain, change or overrule relative verdicts. Or it can accord to Article 52 of ICSID to overall or partially withdraw verdicts. If appellate arbitration withdraws changes or overrules original verdict but does not handle parties' disputes, any party can submit unhandled dispute to a new established arbitration or appellate arbitration can order case to be reviewed by original arbitration court. If appellate arbitration court judges the dispute, the judgment from it is the final binding verdict.

\section{The Composition of Arbitrators}

As the development of international investment, more and more investment disputes will be submitted to ICSID or other arbitration centers. However, ICSID as the only professional institution to resolve international investment disputes, it is still important currently. And the construction of other kind of international arbitration centers servicing for developing countries interests takes time. Moreover we can not make sure the establishment of this kind of regional international arbitration center will resolve all the problems faced by developing countries. Currently, the amount of stuff work in ICSID can not carter the increasing international investment disputes. ICSID do not have its own independent and full-time general secretary. And most arbitrators are from developed countries instead of developing countries. Generally, in their personal opinion, the protection of investors' interest is far more important than the consideration of host countries' public interest or state sovereignty. Therefore, it is necessary to add the amount of arbitrators from developing countries. They familiar with the detailed situation of developing country and that will be possible for them to consider about the need of developing country instead of just protecting investor interest.

\section{References}

[1] See World Bank Group, Bolivia Leaves the ICSID, at http://web.worldbank.org/WBSITE/EXTERNAL/BANCOMUNDIAL/E XTSPPAISES/LACINSPANISHEXT/BOLIVIAINSPANISHEXT/0,,con tentMDK:22766950 pagePK:1497618 piPK:217854 theSitePK:50041 0,00.html,August 2, 2011.

[2] S. P. Kumar, "Rethinking the Linkages between Foreign Direct Investment and Development: A Third World Perspective," NALSAR Student Law Review (E-Jour), Vol. 31, p.38, 2009 at http://www.nalsarstudentlawreview.com/files/Shashank.pdf, August 2, 2011.

[3] C. Binder-U. Kriebaum - A. Reinisch - S. Wittich (ed), International Investment Law for the 21 st. Century, Oxford University Press, 2009, p. 132. 
[4] See Sempra Energy Int'1 v. Argentina Republic. ICSID Case No. $\mathrm{ARB} / 02 / 16$, Award Oct. 28, 2007. Sempra Energy International v. Argentine Republic (ICSID Case No. ARB/02/16). Decision on annulment. June 29, 2010, para 222.

[5] R. A. Uez, Fobia arbitral? Los Arbitrajes en el CIADI y Dos Recomendaciones al Respecto, Argentina del Régimen de la Administración Pública, Section Doctrine, p. 34, June 1, 2006

[6] H. D. Rosatti, Los Tratados Bilaterales de Inversión, el Arbitraje Internacional Obligatorio y el Sistema Constitucional Argentino,
Procuración del Tesoro de la Nación, Jul-Dec Press, 2003, p. 73.

[7] El Ciudadano.gob.ec (periódico digital del gobierno de la revolución ciudadana), Sistema de Solución de Controversias Inicia su Proceso, Dec. 3 2010, at

http://www.elciudadano.gov.ec/index.php?option=com_content\&view=a rticle\&id=19256:sistema-de-solucion-de-controversias-inicia-suproceso, August 2, 2011. 